\title{
Pengaruh Pendidikan Kesehatan Tentang Higiene Menstruasi Terhadap Pengetahuan Remaja Putri
}

\author{
Mariene Wiwin Dolang, Erlin Kiriwenno \\ STIKES Pasapua Ambon \\ Email : marienedolang@gmail.com
}

\begin{abstract}
Abstrak: Penelitian ini bertujuan untuk mengetahui pengaruh pemberian pendidikan kesehatan tentang higiene menstruasi terhadap pengetahuan remaja putri. Penelitian ini merupakan penelitian Pra Eksperimen dengan rancangan One Group Pratest Posttest. Sampel dalam penelitian ini Siswi SMP Negeri 1 masohi yang sudah menstruasi sebanyak 35 siswi. Pengolahan dan analisis data dilakukan dengan komputerisasi dan disajikan dalam bentuk distribusi frekuensi dan tabulasi silang dengan menggunkan uji Indepentent $T$ Test jika data berdistribusi normal dan jika data berdistribusi tidak normal digunakan uji Wilcoxon dengan tingkat signifikansi $p<0,05$. Hasil penelitian ini menunjukkan bahwa ada pengaruh pemberian pendidikan kesehatan terhadap pengetahuan $(p=0,000)$ tentang higiene menstruasi pada siswi di SMP Negeri 1 Masohi. Penelitian ini menyarankan pendidikan kesehatan remaja diharapkan dapat dimasukkan dalam kurikulum pembelajaran dan diberikan secara rutin atau berkala kepada remaja di sekolah.
\end{abstract}

\section{Kata Kunci : Pendidikan Kesehatan, Pengetahuan, dan Higiene Menstruasi,}

Abstract: This study discusses the importance of health education about menstrual hygiene to the knowledge of young women. This research is a Pre Experiment research by designing One Group Pratt Posttest. The sample in this study were 35 male students of SMP Negeri 1 masohi who had menstruated. Data processing and analysis is done by computerization and presented in the form of frequency distribution and cross tabulation by using the Indepentent $\mathrm{T}$ Test if the data is normally distributed and if the data is not normally distributed the Wilcoxon test is used with a significance level of $p<0.05$. The results of this study indicate that there is research on health education on knowledge ( $\mathrm{p}=$ 0,000) about menstrual hygiene for female students at SMP Negeri 1 Masohi. This study discusses adolescent education which is expected to be given in the learning curriculum and given to adolescents in schools.

Keywords: Health Education, Knowledge, and Menstruation Hygiene 
Menstruasi merupakan proses alami yang terjadi pada setiap wanita yang ditandai dengan keluarnya darah dari vagina yang disebabkan karena meluruhnya dinding endometrium. Pada saat menstruasi, pembuluh darah yang terdapat didalam rahim mudah terkena infeksi sehingga para remaja diharapkan dapat menjaga kebersihan alat reproduksi agar terhindar dari penyakit infeksi. Anan tahun 2018 mengungkapkan bahwa Praktik higiene mestruasi yang kurang baik merupakan salah satu penyebab terjadinya infeksi saluran reproduksi (ISR) dan keputihan pada wanita di India. Perilaku higiene menstrusi yang buruk pada remaja di Kota Guwahati India menyebabkan terjadinya infeksi saluran reproduksi $(20,2 \%)$ dan infeksi saluran kemih $(24,4 \%)$ (Barthakur, 2017). Di Kenya terdapat $28 \%$ remaja yang mengalami ISR, 18,2\% bakteri vaginosis, dan 8,6\% candida albicans (Keburo, 2016). Srivasta (2017) dari hasil penelitiannya mengatakan bahwa praktik Higiene menstruasi yang baik, seperti penggunaan pembalut wanita dan melakukan pembersihan pada daerah genetalia merupakan hal yang sangat penting dilakukan selama mestruasi. Infeksi saluran reproduksi, seperi kandidiasis dan trikomonas vaginalis merupakan salah satu menyababkan terjadinya kanker serviks Day, 2016). Kurangnya informasi tentang menstruasi, pengetahuan tentang kesehatan reproduksi dan seksualtas dapat mengurangi kemampuan remaja untuk mengelola kebersihan saat menstruasi (Unicef, 2016)

Salah satu cara yang tepat untuk menambah pengetahuan dan mengubah perilaku adalah dengan pemberian pendidikan kesehatan. Pemberian pendidikan kesehatan merupakan salah satu cara yang tepat untuk merubah gaya hidup masyarakat. Untuk itu sebelum seseorang merubah gaya hidup, mereka harus terlebih dahulu memiliki pengetahuan, sikap, tindakan, dan mendapatkan akses layanan yang baik tentang kesehatan (Laverack, 2017).

Pendidikan kesehatan adalah suatu kegiatan yang dilakukan untuk meningkatkan kemampuan baik dari segi pengetahuan, sikap maupun tindakan agar kehidupan yang sehat dapat tercapai. Pendidikan kesehatan merupakan suatu proses pendidikan secara terencana untuk mencapai tujuan kesehatan melalui beberapa kombinasi atau aplikasi pendidikan dalam bidang kesehatan (Notoatmodjo, 2010). Pendidikan kesehatan merupakan unsur dari program kesehatan untuk mengubah perilaku seseorang maupun masyarakat dengan tujuan agar kesehatan menjadi suatu yang bernilai dimasyarakat sehingga peningkatan kesehatan dapat tercapai. Pendidikan kesehatan yang diberikan secara komperhensif merupakan salah satu cara yang dapat mengurangi kejadian bakteri vaginosis (Bitew, 2017).

Perubahan atau tindakan pemeliharaan dan peningkatan kesehatan yang dihasilkan oleh pendidikan kesehatan ini didasarkan kepada pengetahuan dan kesadarannya melalui proses pembelajaran. Sehingga perilaku tersebut diharapkan akan berlangsung lama (long lasting) dan menetap (langgeng), karena didasari oleh kesadaran.

BIOLOGI SEL (VOL 9 NO 1 EDISI JUN-JUL 2020 ISSN 2252-858X/E-ISSN 2541-1225) PAGE 102 
Pendidikan kesehatan merupakan metode yang tepat untuk memberikan informasi kepada remaja. Perilaku yang didasari pengetahuan lebih tahan lama dibandingkan perilaku yang tidak didasari pengetahuan (Maulana, 2009). Pendidikan kesehatan baik formal maupun non formal harus mendorong perilaku yang melindungi remaja dari masalah kesehatan reproduksi seperti kehamilan yang tidak diinginkan, infeksi menular seksual termasuk HIV/AIDS, pelecehan seksual, kekerasan dan masalah kesehatan reproduksi (WHO, 2011).

Di Indonesia khususnya Maluku Tengah merupakan daerah dengan iklim tropis yang menyebabkan kulit rentan berkeringat sehingga membuat kondisi vagina menjadi lembab. Kelembapan yang tinggi menyebabkan panas pada daerah kewanitaan dan menimbulkan iritasi pada vagina sehingga bakteri mudah berkembang biak (Abrori, 2017). Terbatasnya penelitian terkait kebersihan saat menstruasi di Maluku tengah sampai saat ini berdampak kurangnya pengetahuan tentang kebersihan saat menstruasi. Hasil penelitian yang dilakukan oleh UNICEF di Indonesia pada tahun 2015 merekomendasikan agar pengetahuan dan informasi tentang menstruasi dan kebersihan saat menstruasi lebih ditingkatkan.

\section{METODE PENELITIAN}

Desain penelitian yang digunakan dalam penelitian ini adalah Pra Eksperiment dengan pendekatan The One Group Pratest Posttest. Lokasi penelitian dilaksanakan dilaksanakan di Kota Masohi Kabupaten Maluku tengah yaitu SMP Negeri 1 Masohi dari April s/d Juli 2019. Populasi dalam penelitian ini adalah seluruh siswi SMP Negeri 1 Masohi. Sampel dalam penelitian ini Siswi SMP Negeri 1 masohi yang sudah menstruasi. Pengambilan sampel menggunakan teknik metode proporsional stratified random sampling dengan jumlah sampel sebanyak 35 responden.

Data primer diperoleh langsung dari responden melalui kuesioner pengetahuan, sikap, tindakan, dan higiene menstruasi. Data sekunder diperoleh dari profil dan jumlah siswi di SMP Negeri 1 Masohi dan literature yang berkaitan dengan penelitian. Analisis Data adalah:

1. Analisis univariat

Analisis univariat dilakukan analisis sebaran persentase variabel tunggal termasuk karakteristik umum responden yang disajikan dalam bentuk tabel distribusi frekuensi.

2. Analisis Bivariat

Analisis bivariat dilakukan untuk melihat pengaruh antara variabel independen dan variabel dependen. Jika hasil pengujian normal maka akan digunakan uji Indepentent $T$ Test dan jika data tidak normal digunakan uji Wilcoxon dengan tingkat signifikansi $p<0,05$.

BIOLOGI SEL (VOL 9 NO 1 EDISI JUN-JUL 2020 ISSN 2252-858X/E-ISSN 2541-1225) PAGE 103 


\section{HASIL DAN PEMBAHASAN}

Tabel. 1. Distribusi Responden Berdasarkan Karakteristik Di SMP Negeri 1 Masohi Tahun 2019

\begin{tabular}{|c|c|c|}
\hline Karakteristik & $\mathbf{n}$ & $\%$ \\
\hline \multicolumn{3}{|l|}{ Umur } \\
\hline 13 Tahun & 15 & 42.9 \\
\hline 14 Tahun & 17 & 48.6 \\
\hline 15 Tahun & 3 & 8.6 \\
\hline \multicolumn{3}{|l|}{ Pendidikan Ibu } \\
\hline Tidak Tamat SD & 5 & 14.3 \\
\hline Tamat SD & 2 & 5.7 \\
\hline Tamat SMP & 10 & 28.6 \\
\hline Tamat SMA & 10 & 28.6 \\
\hline Akademi/PT & 8 & 22.9 \\
\hline \multicolumn{3}{|l|}{ Pekerjaan Ibu } \\
\hline IRT & 11 & 31.4 \\
\hline PNS/TNI/POLRI & 1 & 2.9 \\
\hline Pegawai Swasta & 3 & 8.6 \\
\hline Wiraswasta & & \\
\hline Total & 35 & 100 \\
\hline
\end{tabular}

Sumber : Data Primer, 2019

Berdasarkan tabel 1 dapat diketaui bahwa sebagian besar responden berusia 14 tahun yang terdapat sebanyak 48,6\%. Dari tingkat pendidikan ibu, sebagian besar ibu responden Tamat SMP/ SMA $(28,6 \%)$. Berdasarkan Pekerjaan orang tua, rata-rata ibu responden merupakan Ibu Rumah Tagga $(57,1 \%)$

Tabel. 2. Distribusi Responden Berdasarkan Sumber Informasi Terkait Higiene Menstruasi Di SMP Negeri 1 Masohi Tahun 2019

\begin{tabular}{ccc}
\hline Sumber Informasi & n & \% \\
\hline Media Cetak & 16 & 45.7 \\
Media Elektronik & 17 & 48.6 \\
Teman Sebaya & 14 & 40.0 \\
Tenaga Medis/Paramedis & 21 & 60.0 \\
Guru & 17 & 48.6 \\
Orang Tua & 16 & 45.7 \\
\hline
\end{tabular}

Sumber : Data Primer, 2019

Berdasarkan tabel 2 dapat diketahui bahwa lebih dari setegah responden responden memperoleh informasi tentang higiene menstruasi dari Tenaga Medis/Paramedis yang terdapat sebanyak $60,0 \%$. 
Tabel. 3. Distribusi Responden Berdasarkan Pengetahuan Tentang Higiene Menstruasi Sebelum dan Sesudah Diberikan Pendidikan Kesehatan Di SMP Negeri 1 Masohi Tahun 2019

\begin{tabular}{lcccc}
\hline \multicolumn{1}{c}{ Variabel } & Mean & SD & Min. & Maks. \\
\hline Pengetahuan Pre & 20,03 & 4,554 & 12 & 28 \\
Pengetahuan Post & 24,86 & 2,972 & 19 & 29 \\
\hline
\end{tabular}

Sumber : Data Primer, 2019

Berdasarkan tabel 3 dapat diketahui bahwa rata-rata pengetahuan tentang Higiene Menstruasi sebelum diberikan Pendidikan Kesehatan sebesar 20,03 dan setelah diberikan Pendidikan Kesehatan sebesar 24,86. Sebelum diberikan intervensi berupa pendidikan kesehatan nilai skor pengetahuan minimum yang diperoleh responden 12 dan setelah diberikan intervensi nilai skor pengetahuan minimum yang diperoleh responden meningkat menjadi 19.

Tabel 4. Uji Normalitas Variabel Penelitian

\begin{tabular}{lccc}
\hline \multirow{2}{*}{ Variabel Penelitian } & \multicolumn{3}{c}{ Shapiro-Wilk } \\
\cline { 2 - 4 } & Statistik & df & p \\
\hline Pengetahuan Pre & 0.950 & 35 & 0.110 \\
Pengetahuan Post & 0.919 & 35 & 0.013 \\
\hline
\end{tabular}

Sumber : Data Primer, 2019

Berdasarkan tabel 4 menunjukkan bahwa pada uji Test Of Normality Shapiro-Wilk dengan nilai $\mathrm{p}=0,110$ dan $\mathrm{p}=0,013$, karena terdapat nilai $\mathrm{p}<0,05$ maka data tersebut berdistribusi tidak normal sehingga digunakan uji Wilcoxon.

Tabel 5. Pengaruh Pemberian Pendidikan Kesehatan Terhadap Pengetahuan Tentang Higiene Menstruasi Di SMP Negeri 1 Masohi Tahun 2019

\begin{tabular}{lccccc}
\hline & & $\mathrm{n}$ & Mean & $\mathrm{Z}$ & $\mathrm{P}$ \\
\hline Pengetahuan & Negatif Ranks & 3 & 5.00 & & \\
& Positif Ranks & 29 & 17.69 & & \\
& Ties & 3 & & -4.665 & 0,000 \\
& Total & 35 & & & \\
\hline
\end{tabular}

Sumber : Data Primer, 2019

Berdasarkan tabel 6 menunjukkan bahwa sebagian besar responden mengalami peningkatan pengetahuan setelah diberikan pendidikan kesehatan. Hanya terdapat enam responden yang tidak mengalami peningkatan pengetahuan setelah diberikan pendidikan kesehatan. Hasil uji statistik menujukkan bahwa nilai $p=0,000$. Karena nilai $p<0,005$ maka H0 ditolak artinya ada pengaruh pemberian pendidikan kesehatan terhadap pengetahuan tentang higiene menstruasi pada siswi di SMP Negeri 1 Masohi.

Berdasarkan hasil penelitian didapatkan bahwa sebagian besar responden mengalami peningkatan pengetahuan setelah diberikan pendidikan kesehatan yang dapat dilihat dari meningkatnya jumlah responden yang mampu menjawab dengan benar pernyaaan yang diberikan. Meningkatnya pengetahuan responden disebabkan karena penjelasan dan pengarahan yang diberikan dalam suasana yang terbuka, sehingga remaja 
lebih mudah dalam memahami dan mengerti tentang higiene menstruasi dan nantinya dapat memperaktikannya pada saat menstruasi.

Meningkatnya pengetahuan responden dapat dilihat pada beberapa item pertanyaan dimana masih banyak responden yang tidak menjawab dengan benar pertanyaan yang diberikan pada saat pre-test dan setelah diberikan intervensi pendidikan kesehatan, berupa penyuluhan, pemberian modul dan leaflet jumlah responden yang menjawabnya dengan benar setiap pertanyaan menjadi meningkat. Dimana rata-rata skor pengetahuan tentang Higiene Menstruasi sebelum diberikan Pendidikan Kesehatan sebesar 20,03 dan setelah diberikan Pendidikan Kesehatan meningkat menjadi 24,86.

Pengetahuan yang dimiliki oleh seseorang merupakan ukuran dalam memulai suatu tindakan yang dapat dipengaruhi oleh pengalaman seseorang. Berbagai faktor- baik fisik maupun non fisik yang kemudian pengalaman tersebut diketahui, dipersepsikan, diyakini sehingga menimbulkan motivasi, niat untuk bertindak dan bersikap sehingga pada akhirnya terjadi perwujudan niat berupa perilaku. Pengetahuan mempunyai kontribusi yang besar dalam mengubah perilaku seseorang untuk melakukan sesuatu. Notoadmodjo (2012) menyatakan bahwa pengetahuan yang menunjang perilaku perlu diberikan agar individu dapat melakukan tugasnya berdasarkan teori-teori yang dapat dipertanggungjawabkan. Pengetahuan yang dimiliki seseorang memungkinkan orang tersebut akan melakukan hal yang bermanfaat bagi dirinya dari informasi yang didapatkannya.

Salah satu cara untuk meningkatkan pengetahuan adalah memberikan pendidikan kesehatan dalam bentuk penyuluhan, leaflet, maupun memberikan modul. Pendidikan kesehatan dalam bentuk ceramah atau penyuluhan dapat meningkatkan pengetahun, sikap dan memungkinkan juga untuk mengubah perilaku masyarakat Penyuluhan kesehatan pada hakikatnya merupakan suatu kegiatan atau usaha menyampaikan pesan kesehatan kepada masyarakat, kelompok atau individu. Dengan pemberian pendidikan kesehatan diharapkan agar individu bisa mendapatkan pembelajaran yang menghasilkan suatu perubahan dari yang semula belum diketahui menjadi diketahui, dari yang dahulu belum mengerti dapat menjadi dimengerti, dan dapat membawa akibat terhadap perubahan pengetahuan.

Hasil penelitian ini sejalan dengan hasil yang dilakukan oleh Ngestiningrum tahun 2017 yang mengatakan bahwa dengan memberikan ceramah atau penyuluhan dapat meningkatkan pengetahuan remaja tentang perilaku personal hygiene saat menstruasi. Pendidikan kesehatan dengan metode ceramah merupakan metode yang sering digunakan, terlebih untuk massa dengan jumlah yang banyak.. Selain itu hasil penelitian yang dilakukan Miswanto (2014) mengungkapkan bahwa para remaja perlu diberikan pendidikan kesehatan reproduksi dan seksual agar remaja memiliki pemahaman dan pengetahuan sehingga dapat mengurangi terjadinya masalah-masalah terkait kesehatan reproduksi dan seksual.

BIOLOGI SEL (VOL 9 NO 1 EDISI JUN-JUL 2020 ISSN 2252-858X/E-ISSN 2541-1225) PAGE 106 


\section{KESIMPULAN}

Dari hasil penelitian dapat disimpulkan bahwa ada pengaruh pemberian pendidikan kesehatan terhadap pengetahuan tentang higiene menstruasi pada siswi di SMP Negeri 1 Masohi

\section{DAFTAR PUSTAKA}

Abrori Et al. (2017). Faktor Yang Berhubungan Dengan Kejadian Keputihan Patologis Siswi Sman 1 Simpang Hilir Kabupaten Kayong Utara. Unnes Journal Of Public Health Vol. 6 No. 1 Hal 24-34

Anand, Enu, et al. (2018). Menstrual Hygiene Practices And Its Association With Reproductive Tract Infections And Abnormal Vaginal Discharge Among Women In India. Sexual \& Reproductive Healthcare Vol. 6 Issue. 4 Pages 249-254

Barthakur, Chinmayee And Monjuri Barkatak. 2017. A Study On Reproductive Health Problems And Menstrual Hygiene Practices Among Adolesce Nt Girls Living In Slums Of Guwahati City, Assam. National Journal Of Community Medicine Vol. 8 Issue 10 Pages 602-605

Bitew, Adane et al. (2017). Prevalence of Bacterial Vaginosis and Associated Risk Factors among Women Complaining of Genital Tract Infection. International Journal of Microbiology

Dahlan, Sopiyudin. (2016). Statistik untuk Kedokteran dan Kesehatan : Deskriptif, Bivariat, dan Multivariat (Edisi 6). Jakarta : Epidemiologi Indonesia

Dey et al. (2016). Reproductive Tract Infections And Premalignant Lesions Of Cervix:

Evidence From Women Presenting At The Cancer Detection Centre Of The Indian Cancer Society, Delhi, 2000-2012. Journal Obstetri and Gynaecol India. Vo. 66 Sup 1 Pages 441-451

Kerubo, Emili et al. (2016). Prevalence of Reproductive Tract Infections and The Predictive Value of Girl's Sympom-Based Reporting: Findings From A Cross Sectional Survey in Rural Western Kenya. Sexually Transmitted Infection Vol 92 pages $251-256$

Laverack, Glenn. (2017). The Challenge Of Behaviour Change And Health Promotion. Challenges Vol 8 (2), 25 Pp 1-4

Maulana. (2009). Promosi Kesehatan. Jakarta: EGC.

Miswanto. (2014). Pentingnya Pendidikan Kesetahan Reproduksi dan Seksualitas pada Remaja. Jurnal Studi Pemuda Vo. 3 No. 2 Hal. 111-121

Ngestiningrum, Ayesha Hendriana, et al. (2017). Efektifitas Metode "Index Card Match" Dan Ceramah Dalam Meningkatkan Pengetahuan, Sikap Dan Perilaku Personal Hygiene Saat Menstruasi Pada Remaja. 2-Trik : Tunas-Tunas Riset Kesehatan Vol. 7 No. 2 Hal 114-120 
Notoatmodjo Soekidjo. (2010). Promosi Kesehatan Teori Dan Aplikasi Edisi Revisi. Jakarta : Rineka Cipta

Notoatmodjo. S. (2012). Pendidikan dan Perilaku Kesehatan. Jakarta : Rineka Cipta

Srivastava, Shubha. (2017). Analytical Study Of Urinary Tract Infection In Adolescent Girls. International Journal Of Reproduction, Contraception, Obstetrics And Gynecology Vol. 7 Issue 4 Pages 1385-1388

UNICEF. (2016). Supporting The Rights Of Girls And Women Through Menstrual Hygiene Management (MHM) In The East Asia And Pacific Region, Realities, Progress And Opportunitie. UNICEF East Asia And Pacific Regional Office (EAPRO)

UNICEF. (2015). Menstrual Hygiene Management In Indonesia Understanding Practices, Determinants And Impacts Among Adolescent School Girls

WHO. (2011). The Sexual And Reproductive Health Of Younger Adolescents : Research Issues In Developing Countries. http://www.surgeongeneral.gov/initiatives/prevention/strategy/reproductivesexual-health.pdf. Diakses pada 12 September 2019. 